\title{
An Analysis on Consumer Preference of Ayurvedic Products in Indian Market
}

\author{
Richa Misra, Jaipuria Institute of Management, Noida, India \\ Sonali Singh, Jaipuria Institute of Management, Noida, India \\ Renuka Mahajan, Jaipuria Institute of Management, Noida, India
}

\begin{abstract}
With the growing awareness of lifestyle diseases and risk related to chemical-based products, there has been an increasing interest in green/natural products. The purpose of this study is to analyze the recent surge in the growth rate of Ayurved Market and to explore factors that are driving or inhibiting the said pattern. The study will use descriptive statistics and exploratory factor analysis to understand the factor influencing the consumer perception of Ayurvedic products. The study will also investigate the relation between the demographic factors and preference for Ayurvedic products. The study identifies the factors which influence the brand preferences and to know how these factors are further influenced by demographics. The result of the study indicates that the factors of trust and satisfaction have positive and significant impact on the brand preferences, whereas price has negative but insignificant influence on brand preferences. This study is an attempt to understand the role of Ayurved in food science as well as medical science.
\end{abstract}

\section{KEYWORDS}

Ayurveda, Brand Loyalty, Brand Preference, Consumer Demographic Variables, Consumer Preference

\section{INTRODUCTION}

Over last two decades, a significant change has been seen in the buying behavior of Indian consumers. Indian consumers are now more conscious about the environment impact of products and this has led to a major change in their buying behavior. Consumers have started preferring eco-friendly products. The consumption rate of such eco-friendly products in Indian semi-urban and rural market is growing appreciably. FMCG (fast moving consumer goods) industry also banks on them as a significant source of revenue. The ratio of rural-urban population in India is $68.84 \%$ is to $31.16 \%$. This implies that there are immense growth prospects in rural India (indiafacts.in/india-census-2011/ urban-rural-population-of-india). The buying propensity in rural areas is accelerating at a balanced rate. As a result, rural market is reflecting escalation, particularly in product categories like toilet soaps, vanaspati ghee (edible oil), tea, hair oil, talcum powder, etc.

Ayurveda is a system based on the notion of balance, predominantly practiced in India and has been in existence for almost five thousand years. It comprises of diet and herbal remedies, while emphasizing the body, mind and spirit in disease prevention and treatment (Morgan, 2002). The ancient Vedic traditions are deeply embedded in the Indian culture. According to the study by Sawant (2013), the consumers of the rural areas have more trust in nature-based (Ayurvedic) products, as they relate such products to indigenous treatment. In rural areas people of all ages, gender, with 
different academic qualification and income levels share similar perception about such products. According to Sinha and Singh (2015), in India, FMCG competition is continuously rising between the international brands (chemical-based) and the indigenous herbal brands (nature-based) in cosmetic category. In a recent research done by Anute et. al., 2015, it has been found that the younger female population is more attracted towards the natural products and this needs a recalibration amongst the established cosmetic brands to adjust accordingly. The survey, conducted by the Associated Chambers of Commerce and Industry of India (ASSOCHAM), has brought out that seventy-two per cent of the corporate employees are switching to traditional healing therapies like massage and acupressure.

According to Sawant (2013), the general population and specifically the rural population do relate Ayurvedic products with native treatment. This segment is quite promising for any marketer in India, but it also offers its own set of challenges. As per the findings of Kewlani and Singh (2012), brand, advertising, awareness, packaging and availability were important factors that influence the perception of the masses towards specific Ayurved branded products and therapies. According to Thaisorn et. al., (2012), inflation along with the 4 Ps of marketing mix (i.e. product, price, place and promotion), were the crucial factors that influenced the perception of the Thai consumers about herbal cosmetics.

A WHO (World Health Organization) study estimates that about eighty percent of the global population relies on natural products for their health care as compared to modern medicines (Sharma et.al., 2008). The primary reasons for the preference of Ayurvedic products were found as the consequences of using harmful chemical based products and the cost of modern medicines (Sharma et.al., 2008).

Snapdeal, one of the major e-commerce giant in India, has witnessed ninety per cent surge in the sales of Ayurvedic products from the year 2014 to 2015. This significant growth in the preference of herbal products has been observed in all the segments inclusive of health, food, grocery products, fitness and fitness equipment. The mantra of a healthy lifestyle is very popular among customers, specifically those in metros. Patanjali Ayurved is one of the leading and fastest growing Ayurveda giant, led by the well-known yoga guru Baba Ramdev. Patanjali Ayurveda has almost doubled its revenue to 3,266.97 crores as compared to 1,587 crores in the year 2015. Patanjali's growth has defined Ayurveda philosophy as a differentiator for the wellbeing of entire globe and also set a benchmark for the other companies to flourish in Indian market. (http://www.business-standard.com)

Since there is a lot of scope for the growth of herbal products market within the country especially in rural areas and abroad, it would be appropriate to highlight the market potential of herbal products (Sharma et.al., 2008). With these objectives, we tried to review the market potential and the factors responsible for the preference of herbal/Ayurvedic products in India.

\section{LITERATURE REVIEW}

\subsection{Consumers Brand Preference and Demographic Factors}

Consumer brand preference is attributed to the brand performance and to the value of its shares in the market (Sriram et al., 2006). Therefore, understanding the exact need of the customer will help in creating stable brands, which can sustain a long and loyal relationship with consumers. Many researchers have established the relationship between demographic variables and brand preference. The empirical study conducted by Menon, Mahendran and Mahendran, (2015) on gender differences in brand preferences for backpack, found that there was a significant difference in the inclination toward buying a backpack. Male consumers put more emphasis on utility features like sturdiness and quality of zip whereas female has more inclination to attributes like color and design. Taleghani and Taghizadeh, (2012) observed gender-wise differences in perception of consumers as far as brand loyalty is concerned. Impact of advertising and promotion on female consumer is more as compared to male consumers. Female also gets more fascinated by the promotional activities like free gifts, festival discounts and others. Loyalty of male and female can be driven by different reasons. Melnyk 
et al. (2009) found that loyalties of male and female customer are dissimilar. Female consumers are likely to be more loyal than their counterparts. This pattern is inverted when loyalty is measured for a group of people, or an organization. Noble et al. (2006) found that women's loyalty towards organization is determined by social reasons; while men's loyalty to the organization is attributed to the information they collect. As per Perez et. al. (2011) study, brand preference is inherited from one generation to another generation. If the parents are loyal to some product/service, there is a probability that the offspring will also inherit the liking for the same product/service attributed to the trust developed for the same.

The decision making process for buying a particular brand by a consumer is very difficult as it is based on several factors. Consumers' purchase intention is usually related to their behavior, attitude and preference. Purchase behavior plays the most important role while consumers assess a product (Keller, 2001). For predicting the purchase process, purchase intention is an operational instrument (Ghosh, 1990). Once the consumers decide to purchase the product of a particular brand, they will be motivated by their own intention. However, purchase intention might be reformed by the influence of price, perception about quality and preference for the brand (Zeithaml, 1988; Grewal et. al., 1998). Middle-aged female and older generation are the key buyers of the herbal category, especially in the food category. Besides, thoughtfulness to preventative health care have increased the demand for health beneficial herbal supplements. As per the study conducted by Chandiraleka and Hamsalakshmi (2016), the factors that are most important in increasing the brand preference, especially for the Ayurveda products, are the use of natural ingredients and their health benefits.

Growing liking for the herbal products is owed to a 'back to roots' movement, among consumers from different demographic characteristics. This is one upcoming trend, which is expected to have a significant impact on consumer behavior and consumption (Dabur India Limited, Annual Report, 2015-16).

As per the research conducted by Subrahmanian and Venkatesan (2011), it has been found that ageing males are more aware about the Ayurvedic products. But, lack of facility and accessibility to herbal products was the main drawback which influences the preference of such products.

The ability to offer reasonable prices and to successfully meet consumer's expectations are the key ingredients in any marketing campaign, therefore the price concerns both before and after the purchase remains a major concern for marketing managers. Consumer satisfaction is dependent on the value they receive from a product or service, which in turn depends on price to some extent. Price information is a crucial variable in increasing consumer satisfaction. The framework includes comparison of the results across products with different prices in addition to across consumers with different incomes (Chan et al. 2003).

The demographic variables (example; age, gender and income) of a consumer may affect their concern in products in addition to their capability to pay prices (Munnakka, 2008). It has been indicated that the females are the ones who makes the major proportion of purchase of grocery products and are more well-informed about the prices in this category compared to the males (Market Research Bureau. 2004). Estelami (1998) has found a significant impact of demographics on the price knowledge in the grocery shopping industry.

\subsection{Trust}

It has been recognized in the preceding studies, that the brands who have trusting relationships with the customers (Brynjolfsson and Smith, 2000) have noteworthy advantages over other firms. Literature defined three measurements of consumer trust: First one is the 'competence' that is, the capability of the company to satisfy the assurances that were communicated to consumers. Then, the second dimension is 'benevolence' that is, placing the benefit and concern of consumers first before the company's interest. A third dimension is 'integrity' that is, continuously fulfilling the promises (Chen and Dhillon,2003). All these three dimensions are significantly important in terms of Ayurvedic products. As per Arya et.al, (2012) consumers have a positive approach towards Ayurvedic drugs 
and products. In fact, they even use Ayurvedic drugs without a doctor's prescription. Parmar (2007) conducted an empirical study on the usage of cosmetic products. The findings showed that the users preferred either homemade or herbal cosmetics compared to the synthetic cosmetics. Makkar et al. (2007) in their study, concluded that the customers have a significant and positive perception towards herbal cosmetics and these consumers are even willing to purchase premium priced products. Vaish (2006) in his study stated that the majority of the customers have brand loyalty towards Ayurvedic products and there is a growing inclination towards the purchase of herbal products, which are supposed to be less damaging, compared to the chemical based products. The trend is especially observed among the youth (18-24years). The strongest arguments made towards the preference of herbal/Ayurvedic medicines were associated with the fact that the natural products are good for health. As per the study conducted by (Stjernberg, Berglund and Halling, 2006) age and gender affect the use of herbal medicine. The usage of herbal medicines was found to be significantly high in women and elderly people. In general, the preference and usage of herbal products is increasing in western context also (Pharand, Ackmanetal,2003). Canadian patients with cardiovascular disease have relied on the use of herbal products and vitamins, citing the reason of the safe nature of herbal products and less probability of adverse reaction. T statistic was used to test for significant differences of means and percentages between genders and age groups. The study recognized the impact of gender and age-group in evaluating information regarding drug knowledge. As per the empirical study conducted by Mekuria etal (2017) in Ethiopia the use of herbal medicine during pregnancy is a practice and related to residency, level of education and average monthly income. The prime reason cited for the same is traditional and cultural belief in herbal medicines (BMC Complementary and Alternative Medicine, 2017).

Research envisaged herbal remedies as an important part of mainstream medicine in a South African hospital. In general, this will be beneficial to thousands of HIV/AIDS patients who don't have sufficient funds for costly anti-retroviral therapy. (https://www.hst.org.za/news/herbal-remedieswork-wonders-hiv-patients). Finally, trust is a very important construct in determining the brand preference of the consumers.

H1: Trust have positive influence on brand preference.

H1a: Levels of trust vary significantly across consumer demographic variables (a)gender, (b) relationship status, (c) family type, (d) age, (e) qualification, (f) occupation and (g) income.

\subsection{Price}

With liberalization, Indian customers got a chance to select from a wide range of baskets which include synthetic as well as herbal products. Thus, the price will be one of the significant parameters on which their purchasing decision will be built (Hoch, Bradlow and Wansink, 1999). Price has increasingly become a focal point among consumers. The key element of price is what the consumer is prepared/ willing to pay, which will be further associated with a number of other factors including quality.

As per the study of Kotler (2003), irrespective of how a product is, a certain segment of the population will not be capable to pay more than a definite price. The other set of people have the paying capacity; however, they consider that they can spend it somewhere else, leading to more satisfaction. As per the literature, fairness has been defined as a result of whether an outcome and/or the process to reach an outcome are reasonable, acceptable, or justified (e.g., Bolton, Warlop, and Alba 2003).

On the other hand, low-price is not the only criterion; there must be some minimum expectation from the product that must be fulfilled. In case of high-end products, premium pricing creates more desirability for the products as compared to a moderately priced or low priced one (Vigneron and Johnson, 2004). Amount paid for a product is one of the components of cost experienced by consumers. Other components include time spent, transposition cost and emotional costs. Price is one of the critical variables that plays an important role in their buying decision. As per the result of a recent study where 
the objective was to find the determinants in consumer selection of a product; the result indicates price consistently as a major influencing factor (GfK Shopping Monitor, 2016). Such a finding is aligned with the frame of mind of retailers, who specified price as a significant criterion to measure consumer selection of product (Agardi and Bauer, 2007). It is also experienced that the emotional benefit not only comes with high pricing, a medium-priced brand that offers satisfying experience to the users are also as preferred as a premium brand. A fair and reasonable pricing is directly proportional to the customer satisfaction and results in profitability for the company. (Herrmann et al., 1992). According to Byung and Kannan (1999) price perceptions directly influence satisfaction judgments. If the services received are more than what customer expected from the brand, customer experience with the product will lead to higher customer satisfaction. People perceive that the higher price of a product means more liquidity for the resources. This leads to high quality product and the lower price indicates less resource, which is a limitation in producing a higher quality product.

H2: Price has negative impact on brand preference.

H2a: There is a significant difference among the perception for reasonable price across consumer demographic variables (a)gender, (b) relationship status, (c) family type, (d) age, (e) qualification, (f) occupation and (g) income.

\subsection{Satisfaction}

Customer satisfaction may be defined as how products and services produced by a company are able to meet or exceed customer's expectations. Customer satisfaction is a critical construct in deciding customer's prospective purchases (Mittal \& Kamakura, 2001). As per Parasuraman et al. (1991) satisfaction is a result drawn after the experience. For formulating a successful product/service, the company must conduct consumer studies to understand what attribute of product or service are most liked by the consumer. For any food or medicinal product, safety and quality are of highest priority and they are the key enabler in attaining and retaining trust of the consumer. The prime aim of any company is to increase profits and to reduce cost. One of the major reasons that can lead to increase in sales is customer satisfaction (Wilson et al., 2008, p. 79). As the competition increases, it is the utmost need of every company to satisfy their customers to increase sales and profit.

As per (Rekha and Gokila, 2015) many consumers experienced one or more chemicals in the cosmetics, which could lead to many side effects. Hence, they have started moving to herbal based cosmetics. Most of the cosmetic manufacturing company, after assessing the need of the consumer, started providing herbal based cosmetics. As per the empirical study conducted by Kaur (2016) (http:// eminencejournal.com/images/pdf/Z10.pdf), most of the people surveyed were found to be satisfied with the quality and price of herbal cosmetic products (Khanna, 2015). Their study concludes, the majority of the users were satisfied from Patanjali products. The reasons for the same are rational price of the product as well as capability of the product to treat the problem.

Satisfaction may be subjected on both psychological and physical variables. Consumers globally are turning for green/organic products and this is very much apparent in the cosmetics market. Ayurvedic and traditional Chinese medicines are globally acknowledged for their natural constituents and various benefits. Consumers are becoming sensible and do care for the raw materials/ingredients that constitute the product that they are going to use. They are also resistant to chemicals that may lead to adverse effects. Joshi (2008) in his study concluded that the opinion of people for herbal/Ayurvedic medicine is positive and underlined the need to encourage the practice of herbal medicines. Customer satisfaction is a critical differentiator and helps in retaining customers and attaining new ones.

H3: Satisfaction has a positive influence on brand preference.

H3a: Satisfaction levels vary significantly across consumer demographic variables (a)gender, (b) relationship status, (c) family type, (d) age, (e) qualification, (f) occupation and (g) income. 


\section{DESIGN OF STUDY}

\subsection{Context of the Study}

The current research intends to measure the impact of demographic variables on the factors affecting the brand preference of Ayurvedic products. The research was conducted in different phases. The first phase included a literature review and preparation for the study. In the second phase, a pilot study was conducted to understand the applicability of the instrument and pros and cons of the research. The data were collected in the third phase, whereas in the last phase, data analysis was conducted.

\subsection{Questionnaire Design}

Structured questionnaire was used for collecting the data. The questionnaire consists of three sections. The questions included in the first section of the questionnaire, intends to measure the consumer's wakefulness for Ayurvedic products, whereas items included in the second section was to understand and identify the factors which affects the preference of the consumer towards Ayurvedic products. All the items included in the second section were measured in 5-point Likert scale $(1=$ Strongly Disagree to $5=$ Strongly Agree). The last section of the questionnaire included the questions seeking the demographic information of the respondents and their levels of health consciousness. After the successful completion of pilot study, data was collected in the month of September 2016, which was self-administered by the researchers.

\subsection{Sample and Data Collection}

A total of 280 questionnaires were distributed out of which 160 questionnaire responses were returned. Further, there were 9 questionnaires with incomplete information and hence not found relevant for the analysis, leading to a final response rate of 53.9 percent. Respondents from Delhi NCR region participated in the study; the reason being, it is one of the densely populated and diversified urban regions of India. Nonprobability convenience sampling method was used to select the participant of the study. The data were analyzed using IBM, SPSS (Version 20). Exploratory factor analysis was used to identify the factors affecting the brand preference of the Ayurvedic products. Further, regression analysis was used to measure the impact of identified factors on brand preference. To test the hypotheses related to demographic variables T-test and ANOVA were used.

\section{DATA ANALYSIS AND RESULTS}

The present study includes seven demographic variables - gender, relationship status, family type, age, qualification, occupation and income. Based on the literature, it has been observed that the factors influencing consumer preference for the brand differ significantly with respect to the mentioned demographic variables, consequently they have been used in the study (Table 1).

\subsection{Reliability Analysis}

To test the reliability of the scale, Cronbach's Alpha method has been used. The internal consistency is judged as per the acceptable Cronbach's alpha levels. For the instrument, the Cronbach's alpha was 0.86 . Face validity of the instrument was tested and it was found to be very high. The researcher also attempted to establish the construct validity of the instrument through discussions with eminent professors in the area of marketing, retailers and consumers.

Bartlett's test of Sphericity and KMO test was implemented to check the suitability of data for applying factor analysis. Higher value of KMO (greater than 0.5 ) shows that the factor analysis can be applied to the given data, whereas a low value of KMO (below the 0.5) suggests that applying factor analysis may not be suitable. For the current study, the Barteltt's test of sphericity $\left(\chi^{2}=1855\right.$; $\mathrm{df}=136 ; \mathrm{p}=.000)$ and $\mathrm{KMO}(0.88)$ indicates that the data are appropriate for factor analysis. Thus, 
Table 1. Sample demographics

\begin{tabular}{|c|c|c|}
\hline Demographics & Frequencies & Percentage \\
\hline \multicolumn{3}{|l|}{ Age } \\
\hline Young (15-30 years) & 74 & 49.0 \\
\hline Middle Aged (30-50 years) & 64 & 42.4 \\
\hline Old (Above 50 years) & 13 & 8.6 \\
\hline \multicolumn{3}{|l|}{ Gender } \\
\hline Male & 59 & 39.1 \\
\hline Female & 92 & 60.9 \\
\hline \multicolumn{3}{|l|}{ Relationship Status } \\
\hline Single & 48 & 31.8 \\
\hline Married & 103 & 68.2 \\
\hline \multicolumn{3}{|l|}{ Occupation } \\
\hline Student & 45 & 29.8 \\
\hline Servicemen & 38 & 25.2 \\
\hline Businessmen & 44 & 29.1 \\
\hline Housewife & 24 & 15.9 \\
\hline \multicolumn{3}{|l|}{ Education } \\
\hline Less than graduate & 12 & 7.9 \\
\hline Graduate & 75 & 49.7 \\
\hline Post Graduate & 49 & 32.5 \\
\hline Doctorate and higher & 15 & 9.9 \\
\hline \multicolumn{3}{|c|}{ Monthly Household Income (in INR) } \\
\hline Up to 15000 & 7 & 4.6 \\
\hline $15000-30000$ & 31 & 20.5 \\
\hline $30000-45000$ & 74 & 49.0 \\
\hline 45000 \& Above & 39 & 25.8 \\
\hline \multicolumn{3}{|l|}{ Family Type } \\
\hline Nuclear & 49 & 32.5 \\
\hline Joint & 102 & 67.5 \\
\hline
\end{tabular}

it confirmed that the exploratory factor analysis can productively be applied on the items considered for the present study (Tavşancil, 2010). Factors that measures brand preference were identified and named as trust, reasonable price and satisfaction. A total of 65.09 percent of variance was explained by these factors. The items with factor loading less than 0.50 were removed. The results of the factor analysis are presented in Table 2.

\subsection{Multiple Regression Analysis}

Multiple regression analysis was further conducted to identify the impact of trust, reasonable price and satisfaction on the preference for Ayurvedic products. It will further ascertain that what percentage 
Table 2. Factor analysis

\begin{tabular}{|c|c|c|c|c|}
\hline Factors & Measurements & $\begin{array}{l}\text { Factor } \\
\text { loading }\end{array}$ & Eigenvalue & $\begin{array}{l}\text { Cronbach } \\
\alpha\end{array}$ \\
\hline \multirow[t]{5}{*}{ Trust } & high quality natural and genuine raw material & 0.598 & \multirow[t]{5}{*}{8.268} & \multirow[t]{5}{*}{0.81} \\
\hline & high medicinal value & 0.872 & & \\
\hline & $\begin{array}{l}\text { more safer in contrast to other chemical based } \\
\text { products }\end{array}$ & 0.826 & & \\
\hline & Wide range of products & 0.705 & & \\
\hline & $\begin{array}{l}\text { highly associated with the philosophy of Yog- } \\
\text { gurus. }\end{array}$ & 0.625 & & \\
\hline \multirow[t]{3}{*}{ Reasonable Price } & decently priced & 0.651 & \multirow[t]{3}{*}{1.621} & \multirow[t]{3}{*}{0.683} \\
\hline & quality matches with the price charged & 0.761 & & \\
\hline & products relatively cheaper & 0.715 & & \\
\hline \multirow[t]{5}{*}{ Satisfaction } & happy that this range is available & 0.580 & \multirow[t]{5}{*}{1.177} & \multirow[t]{5}{*}{0.895} \\
\hline & more preferred & 0.537 & & \\
\hline & fulfill my needs & 0.734 & & \\
\hline & look forward to use these products & 0.602 & & \\
\hline & $\begin{array}{l}\text { I shall continue to purchase Ayurvedic } \\
\text { products. }\end{array}$ & 0.670 & & \\
\hline
\end{tabular}

of variance in preference for Ayurvedic products is explained by its predictors i.e. trust, reasonable price and satisfaction.

The results obtained from multiple linear regression indicates that the identified factors such as trust, reasonable price and satisfaction have worked well in explaining $54.5 \%$ of variation in the preference of the Ayurvedic product $(\mathrm{F}=58.59 ; \mathrm{p}=0.000)$. From Table 3, it is clear that both trust and satisfaction have a significant positive impact on the preference for Ayurvedic products, whereas price exerts negative influence on the preference for Ayurvedic products. Although, in the present study, the price does not show any significant effect on the predicted variable. The results are in alignment with the previous studies done by Chiou \& Droge, 2006; Ozer \& Aydin, 2004, Shi et. al., 2006. Further t-test and ANOVA was used to study the demographic differences in the factors namely trust, reasonable price and satisfaction responsible for the preference of the consumer for Ayurvedic products.

Table 3. Regression analysis

\begin{tabular}{|c|c|c|c|c|c|c|}
\hline Hypothesis & $\begin{array}{c}\text { Independent } \\
\text { variable }\end{array}$ & $\begin{array}{c}\text { Dependent } \\
\text { variable }\end{array}$ & & & & \\
\hline & & & \multicolumn{2}{|c|}{ Beta } & $\mathrm{R}^{2}$ (Adjusted $\mathrm{R}^{2}$ ) & F-Value \\
\hline $\mathrm{H} 1$ & Trust & \multirow{3}{*}{$\begin{array}{l}\text { Preference } \\
\text { for Ayurvedic } \\
\text { products }\end{array}$} & $0.409 * *$ & \multirow{3}{*}{$0.545(0.535)$} & & \multirow{3}{*}{$58.59 * * *$} \\
\hline $\mathrm{H} 2$ & $\begin{array}{l}\text { Reasonable } \\
\text { Price }\end{array}$ & & -0.204 & & & \\
\hline $\mathrm{H} 3$ & Satisfaction & & $0.769 * * *$ & & & \\
\hline
\end{tabular}




\subsection{T-Test and ANOVA}

T-test for Independent samples is used when we need to test that two-population means are significantly different from each other. Here, this test is being carried out to find that whether the factors affecting the brand preference differ significantly with respect to the demographic variables like gender, relationship status and family type. One-way ANOVA is an extension of independent sample t-test. One-way ANOVA is a statistical technique, to test that the mean of three of more groups is significantly different, i.e. it helps us to test that the mean value of a variable differs significantly among three or more groups of a factor. So, for other demographic variables like age, education, occupation and income with more than two groups, ANOVA is used to make comparison for the factors. Further, to identify the pair-wise differences in the preferences of consumer of different age, qualification, occupation and income groups, Duncan's post hoc test was applied. The results of independent sample t-test and ANOVA are tabulated as follows:

\subsubsection{Influence of Demographic Variables on Trust}

Table 4 and 5 explains, that as far as trust is concerned, the results are statistically significant ( $<<$ 0.05 ) with respect to the demographic variables like gender, family type, occupation and income, whereas for other demographic variable like age, education and relationship status, the results are not statistically significant $(\mathrm{p}>0.05)$. That is, with respect to the demographic variables gender, family type, occupation and income; there exists different groups within the variables for which the mean differs significantly. The results of Duncan post-hoc test applied along with ANOVA indicates that with respect to the occupation, businessmen and housewives have high level of trust as compared to students and servicemen. Probably they are more professional and autonomous in making their decisions. This is because the students are dependent on their parents and a service professional thinks a lot before making any purchase decision. These two groups may also differ in terms of their consumption pattern, the way of handling information, the process of making decisions and personas. Whereas with respect to the income groups, those who belong to high income group may trust easily in contrast to those who belong low- or medium-income group.

\subsubsection{Influence of Demographic Variables on Reasonable Price}

Table 4 and 5 explains the results with respect to next factor that is perceived reasonable price. It has been observed that the results are statistically significant $(\mathrm{p}<0.05)$ with respect to gender, family type and income, whereas for the other demographic factors like relationship status, age, occupation and education, the results are statistically insignificant $(\mathrm{p}>0.05)$. For identifying significantly different groups within the income level, Duncan's post-hoc test was applied. It was found that the people from high income groups are less bothered about the fairness of price in comparison to the people from low- and middle-income group.

\subsubsection{Influence of Demographic Variables on Satisfaction}

For the last factor, i.e. satisfaction, the differences with respect to the demographic factors like age, occupation, income, gender and family type are really significant $(\mathrm{p}<0.05)$, but for the other two demographic variables i.e. education and relationship status the results are not statistically significant $(p>0.05)$. These results are mentioned in Table 4 and 5. For variables such as age, occupation and income, Duncan's post-hoc test was applied to identify the significantly different groups with respect to satisfaction. It was found that the old aged people easily got satisfied in comparison to the young people. This may be because of the reason that young people like to explore, and they are more curious. Also, students, housewives and self-employed people were found to be more satisfied in contrast to service professional whereas with respect to income, people from the middle-income group are more satisfied than low and high income group. 
Table 4. T-test

\begin{tabular}{|c|c|c|c|c|c|}
\hline \multicolumn{2}{|c|}{ Trust } & Mean & SD & t-value & p-value \\
\hline \multirow[t]{2}{*}{ Gender } & Male & 4.09 & 0.69 & $-2.023 * *$ & 0.046 \\
\hline & Female & 4.31 & 0.52 & & \\
\hline \multirow[t]{2}{*}{ Relationship Status } & Single & 4.15 & 0.64 & -1.046 & 0.298 \\
\hline & Married & 4.26 & 0.58 & & \\
\hline \multirow[t]{2}{*}{ Family Type } & Nuclear & 3.91 & 0.69 & $-4.298 * * *$ & 0.000 \\
\hline & Joint & 4.38 & 0.49 & & \\
\hline \multicolumn{2}{|c|}{ Reasonable Price } & Mean & SD & t-value & p-value \\
\hline \multirow[t]{2}{*}{ Gender } & Male & 3.93 & 0.66 & $-2.204 * *$ & 0.029 \\
\hline & Female & 4.16 & 0.59 & & \\
\hline \multirow[t]{2}{*}{ Relationship Status } & Single & 4.03 & 0.58 & -0.500 & 0.618 \\
\hline & Married & 4.09 & 0.65 & & \\
\hline \multirow[t]{2}{*}{ Family Type } & Nuclear & 3.88 & 0.70 & $-2.404 * *$ & 0.019 \\
\hline & Joint & 4.16 & 0.57 & & \\
\hline \multicolumn{2}{|c|}{ Satisfaction } & Mean & SD & t-value & p-value \\
\hline \multirow[t]{2}{*}{ Gender } & Male & 4.12 & 0.81 & $-2.280 * *$ & 0.025 \\
\hline & Female & 4.40 & 0.60 & & \\
\hline \multirow[t]{2}{*}{ Relationship Status } & Single & 4.27 & 0.73 & -0.210 & 0.834 \\
\hline & Married & 4.30 & 0.69 & & \\
\hline \multirow[t]{2}{*}{ Family Type } & Nuclear & 3.91 & 0.69 & $-4.025 * * *$ & 0.000 \\
\hline & Joint & 4.38 & 0.49 & & \\
\hline \multicolumn{6}{|c|}{ Note: $* * * \mathrm{p}<0.01$ ( $1 \%$ level of significance) ${ }^{* *} \mathrm{p}<0.05$ (5\% level of significance) } \\
\hline
\end{tabular}

\section{CONCLUSION AND IMPLICATION}

The study was undertaken with the objective of identifying the factors which influence the brand preference and to know how these factors are further influenced by demographics. A total of six hypotheses were formulated during the study. Although all results were not significant but has supported all the postulated hypothesis which are consistent with the previous studies (Chinomona et.al., 2013; Chaudhuri \& Moris, 2001; Hong and Cho, 2011). The results of the study indicate that trust and satisfaction have a positive and significant impact on brand preference, whereas price has negative but insignificant influence on brand preference. Price of the product may not be an important criterion for the customers, however, once they have established trust on the product and are satisfied with it. Satisfaction and trust were identified as significant factors which influence the preference of Ayurvedic products, whereas the reasonable price of the product was found important but not significant in preference of Ayurvedic products.

Ayurveda is a five-thousand-year old science. Ayurveda's are honored to be a part of this longstanding science, still the research in the field of Ayurveda lacks both direction and quality. The awareness and preference for Ayurvedic products is growing, consequently the number of stores selling Ayurvedic products are also increasing in India. Ayurveda has its legacy in Indian Vedas and has a rich heritage in Indian medicine. In the history of India there are evidences that Ayurvedic medicines have been used to cure the small ailments ranging from digestive disorders to ailments 


\begin{tabular}{|c|c|c|c|c|c|c|c|c|c|c|}
\hline \multicolumn{2}{|c|}{ Demographic variables } & \multicolumn{3}{|l|}{ Trust } & \multicolumn{3}{|c|}{ Reasonable Price } & \multicolumn{3}{|c|}{ Satisfaction } \\
\hline & & \multirow{2}{*}{$\begin{array}{l}\text { Mean } \\
4.20\end{array}$} & \multirow{2}{*}{$\begin{array}{l}\text { SD } \\
.61\end{array}$} & \multirow{2}{*}{$\frac{\mathbf{F}}{1.433}$} & \multirow{2}{*}{$\begin{array}{l}\text { Mean } \\
4.20\end{array}$} & \multirow{2}{*}{$\frac{\text { SD }}{.59}$} & \multirow{2}{*}{$\frac{\mathbf{F}}{0.312}$} & \multirow{2}{*}{$\begin{array}{l}\text { Mean } \\
4.26\end{array}$} & \multirow{2}{*}{$\begin{array}{l}\text { SD } \\
.96\end{array}$} & \multirow{2}{*}{$\frac{\mathbf{F}}{2.467^{* *}}$} \\
\hline Age & $15-19$ & & & & & & & & & \\
\hline & $20-30$ & 4.24 & .58 & & 4.08 & .52 & & 4.36 & .57 & \\
\hline & $31-40$ & 4.37 & .52 & & 4.07 & .74 & & 4.42 & .61 & \\
\hline & $51-50$ & 4.05 & .60 & & 4.00 & .62 & & 4.17 & .63 & \\
\hline & $51 \&$ Above & 4.06 & .85 & & 3.97 & .81 & & 3.78 & 1.09 & \\
\hline \multirow[t]{4}{*}{ Qualification } & Less than Graduate & 4.42 & .54 & \multirow[t]{4}{*}{1.915} & 4.25 & .41 & \multirow[t]{4}{*}{0.768} & 4.37 & .91 & \multirow[t]{4}{*}{1.104} \\
\hline & Graduate & 4.31 & .55 & & 4.08 & .64 & & 4.38 & .55 & \\
\hline & Post Graduate & 4.09 & .69 & & 3.99 & .68 & & 4.16 & .85 & \\
\hline & Doctorate \& higher & 4.12 & .51 & & 4.18 & .50 & & 4.20 & .67 & \\
\hline \multirow[t]{4}{*}{ Occupation } & Student & 4.20 & .62 & \multirow[t]{4}{*}{$3.380^{* *}$} & 4.02 & .59 & \multirow[t]{4}{*}{0.694} & 4.33 & .69 & \multirow[t]{4}{*}{$3.817^{* *}$} \\
\hline & Housewife & 4.42 & .41 & & 4.14 & .62 & & 4.48 & .45 & \\
\hline & Businessmen & 4.46 & .57 & & 4.13 & .62 & & 4.30 & .73 & \\
\hline & Servicemen & 3.93 & .77 & & 3.94 & .73 & & 3.89 & .85 & \\
\hline \multirow[t]{4}{*}{ Income } & Less than 15000 & 4.11 & .77 & \multirow[t]{4}{*}{$16.436^{* * *}$} & 4.00 & .67 & \multirow[t]{4}{*}{$7.441^{* * *}$} & 4.02 & .75 & \multirow[t]{4}{*}{$15.383^{* * *}$} \\
\hline & $15000-30000$ & 4.47 & .35 & & 4.29 & .43 & & 4.56 & .38 & \\
\hline & $30000-45000$ & 4.40 & .46 & & 4.18 & .54 & & 4.49 & .46 & \\
\hline & $45000 \&$ Above & 3.73 & .68 & & 3.70 & .76 & & 3.74 & .93 & \\
\hline
\end{tabular}

as complicated as cancer. These products are cheaper in comparison to synthetic chemical-based products and trusted by people as they are supposed to have no side effects.

With the growth in the market of Ayurvedic products in India, India would get the response from the whole world as these eco-friendly products are in congruence with the nature. Ayurveda has been relishing the universal resurgence. Ayurveda got the appreciation and has been accepted worldwide. Over the years, especially in recent decade, Ayurveda has become prevalent in the segment of food supplements. People consider Ayurvedic products not as cure but they have become a way of life for the customers (Arya, Kumar, \& Kumar, 2012). Customer are positive about Ayurvedic products and give emphasis to strengthen the Ayurved ecosystem (Joshi, 2008). Ayurveda has definitely a potential to meet medical requirements for the masses, especially for those who have been deprived from basic medical facility and all the stakeholders, including government, are contended to make Ayurveda as a mainstream medical system (Sen and Chakraborty, 2015).

There is a dire need to put the accent on on the necessity to initiate a research in Ayurveda, so that ancient Ayurvedic practices which have been followed in India for long could be validated. The flip side is there is a paucity of research being done in the field of Ayurveda as it is being practiced. Although the philosophies of Ayurveda are always relevant, however, there is a necessity to be upto-date with the latest scientific trends for the society as well as for developing Ayurveda science. Government of India is entering into an agreement with the World Health Organization to promote Ayurveda Globally. The Government stands firm to make Ayurveda as the most preferred healthcare system of the country.

Together with a proper marketing strategy, sound agricultural and manufacturing practice, Indian Ayurvedic company can capture good share of market globally. 


\section{REFERENCES}

Agárdi, I., \& Bauer, A. (2007). Kiskereskedelmi stratégiai szövetségek hatása. (The impact of strategic partnerships on the retail market). Vezetéstudomány, 38(1), 25-34.

Anute, N., Deshmukh, A., \& Khandagale, A. (2015). Consumer Buying Behavior towards Cosmetic Products. International Journal in Management and Social Science, 3(7), 25.

Arya, V., Kumar, S., \& Kumar, S. (2012). Consumer Buying Behaviour Towards Ayurvedic Mediciens/Products in Joginder Nagar (Himachal Pradesh)-A Survey. Ayurpharm - International Journal of Ayurveda and Allied Sciences, 1(3), 60-64.

Barkat, R. (2018). Exploring the factors influencing adoption of m-commerce for fashion products in Bangladesh. International Journal of Advanced Research and Review, 3(3), 61-90.

BMC Complementary and Alternative Medicine BMC Series. (2017). https://bmccomplementalternmed. biomedcentral.com/articles/10.1186/s12906-017-1608-4

Bolton, L. E., Luk, W., \& Joseph, W. A. (2003). Consumer Perceptions of Price (Un)Fairness. The Journal of Consumer Research, 29(March), 474-491. doi:10.1086/346244

Brynjolfsson, E., \& Smith, M. (1999). Frictionless Commerce? A Comparison of Internet and Conventional Retailers. Management Science, 46(4), 563-585.

Byung-Do, K., \& Kannan, S. (1999). Identifying Price Sensitive Consumers: The Relative Merits of Demographic Vs. Purchase Pattern Information. Journal of Retailing, 75(2), 173-193. doi:10.1016/S0022-4359(99)00003-2

Chan, L., Hui, Y., Lo, H., Tse, S., Tso, G., \& Wu, M. (2003). Consumer satisfaction index: New practice and findings. European Journal of Marketing, 37(5), 872-909. doi:10.1108/03090560310465189

Chaudhuri, A., \& Holbrook, B. M. (2001). The Chain of Effects From Brand Trust And Brand Affects To Brand Performance: The Role of Brand Loyalty. Journal of Marketing, 65(2), 81-93. doi:10.1509/jmkg.65.2.81.18255

Chen, S. C., \& Dhillon, G. S. (2003). Interpreting Dimensions of Consumer Trust in E-Commerce. Information Technology and Management, 4(2/3), 303-313. doi:10.1023/A:1022962631249

Chinomona, R., Mahlangu, D., \& Pooe, D. (2013). Brand Service Quality, Satisfaction, Trust and Preference as Predictors of Consumer Brand Loyalty in the Retailing Industry. Mediterranean Journal of Social Sciences, 4(14), 181-190. doi:10.5901/mjss.2013.v4n14p181

Chiou, J. S., \& Droge, C. (2006). Service quality, trust, specific asset investment, and expertise: Direct and indirect effects in a satisfaction-loyalty framework. Journal of the Academy of Marketing Science, 34(4), 613-627. doi: $10.1177 / 0092070306286934$

Estelami, H. (1998). The price is right... or is it? Demographic and category effects on consumer price knowledge. Journal of Product and Brand Management, 7(3), 254-266. doi:10.1108/10610429810222886

Ghosh, A. (1990). Retail management. Dryden Press.

Grewal, D., Kent, B. M., \& Krishnan, R. (1998). The Effects of Price-Comparison Advertising on Buyers' Perceptions of Acquisition Value, Transaction Value and Behavioral Intentions. Journal of Marketing, 62, 46-59.

Herrmann, A., Xia, L., Monroe, K. B., \& Huber, F. (2007). The Influence of Price Fairness on Consumer Satisfaction: An Empirical Test in the Context of Automobile Purchases. Journal of Product and Brand Management, 16(1), 49-58. doi:10.1108/10610420710731151

Hoch, S. J., Bradlow, E. T., \& Wansink, B. (1999). The Variety of an Assortment. Marketing Science, 18(4), 527-546. doi:10.1287/mksc.18.4.527

Hong, I. B., \& Cho, H. (2011). The Impact of Consumer Trust on Attitudinal Loyalty and Purchase Intention in B2C E-marketplace: Intermediary Trust vs. Seller Trust. International Journal of Information Management, 31(5), 469-479. doi:10.1016/j.ijinfomgt.2011.02.001

Joshi, K. (2008). Indian Herbal Sector. Retrieved May 22, 2015, from NISTADS / CSIR: http://www.nistads. res.in/indiasnt2008/t4industry/t4ind19.htm 
Juha, M. (2008). Customers' purchase intentions as a reflection of price perception. Journal of Product and Brand Management, 17(3), 188-196. doi:10.1108/10610420810875106

Keller, K. L. (2001). Building customer-based brand equity: A blueprint for creating strong brands. Marketing Management, 10(2), 14-19.

Kewlani, S., \& Singh, S. (2012). Prospects of Traditional Therapy: Consumer's Perception an Empirical Study of Rural Market with Special Reference to Indore District. International Journal of Research in Computer Application \& Management, 2(8), 10.

Khanna, R., (2015). Customer Perception towards Brand: A Study on 'Patanjali'. Global Journal of Management and Business Research: E Marketing, 15(9), 40-45.

Kotler, P., Hessekiel, D., \& Lee, N. (2012). Good Works! Marketing and Corporate Initiatives that Build a Better World... and The Bottom Line. Wiley India. doi:10.1002/9781119205210

Makkar, H. P., Francis, G., \& Becker, K. (2007). Bioactivity of phytochemicals in some lesser known plants and their effects and potential applications in livestock and aquaculture production systems. Animal, 1(9), 1371-1391. doi:10.1017/S1751731107000298 PMID:22444893

Mekuria, W., Veldkamp, E., Haile, M., Nyssen, J., Muys, B., \& Gebrehiwot, K. (2007). Effectiveness of exclosures to restore degraded soils as a result of overgrazing in Tigray, Ethiopia. Journal of Arid Environments, 69(2), 270-284. doi:10.1016/j.jaridenv.2006.10.009

Melnyk, V., Van Osselaer, S. M. J., \& Bijmolt, T. H. A. (2009). Are women more loyal customers than men? Gender differences in loyalty to firms and individual service providers. Journal of Marketing, 73(4), 82-96. doi: $10.1509 / j m k g .73 .4 .082$

Mittal, V., \& Kamakura, W. A. (2001). Satisfaction, Repurchase Intent, and Repurchase Behaviour: Investigating the Moderating Effect of Customer Characteristics. JMR, Journal of Marketing Research, 38(1), 131-142. doi:10.1509/jmkr.38.1.131.18832

Morgan, C. (2002). Medicine of the Gods: Basic Principles of Ayurvedic Medicine. Mandrake of Oxford.

Muhammed, M. A. (2009). Impact of impact quality trust, and customer satisfaction on customer loyalty. American Bar Association Journal. American Bar Association, 29, 27.

Noble, S. M., Griffith, D. A., \& Adjei, M. T. (2006). Drivers of local merchant loyalty: Understanding the influence of gender and shopping motives. Journal of Retailing, 82(3), 177-188. doi:10.1016/j.jretai.2006.05.002

Ozer, G., Aydin, S., \& Arasil, O. (2005). Customer Loyalty and Effect of Switching Costs as a Moderator Variable. Marketing Intelligence \& Planning, 23(1), 89-103. doi:10.1108/02634500510577492

Parasuraman, A., Zeithaml, V. A., \& Berry, L. L. (1991). Refinement and reassessment of the SERVQUAL scale. Journal of Retailing, 67(4), 420-450.

Parmar, A. (2007). Crime and the 'Asian Community': disentangling perceptions and reality (Unpublished doctoral thesis). University of Cambridge, Institute of Criminology.

Paul, J., \& Rana, J. (2012). Consumer behavior and purchase intention for organic food. Journal of Consumer Marketing, 29(6), 412-422. doi:10.1108/07363761211259223

Perez, M. E., Padgett, D., \& Burgers, W. (2011). Inter-generational Influence on Brand Preferences. Journal of Product and Brand Management, 20(1), 5-13. doi:10.1108/10610421111107978

Pharand, C., Ackman, M. L., Jackevicius, C. A., Paradiso-Hardy, F. L., \& Pearson, G. J. (2003). Use of OTC and herbal products in patients with cardiovascular disease. The Annals of Pharmacotherapy, 37(6), 899-904. doi:10.1345/aph.1C163 PMID:12773082

Rekha, M. B., \& Gokila, K. (2015). A study on consumer awareness, attitude and preference towards herbal cosmetic products with special reference to Coimbatore city. International Journal of Interdisciplinary and Multidisciplinary Studies, 2(4), 96-100.

Sathish, M., Menon, S., \& Mahendran, Y. (2015). Gender differences in Buying Behavior and Brand preferences towards Backpack. Journal of Business and Management, 4(4), 12-27. 
Sawant, R. V. (2013). Consumer's Perception for Ayurvedic Therapy in Rural Market with Special Reference to Nashik District. Audyogik Shikshan Mandal's (ASM) International E-Journal of On-Going Research in Management and IT, 1-5.

Sen, S., \& Chakraborty, R. (2015). Towards the Integration and Advancement of Herbal Medicine: A focus on Traditional Indian Medicine. Botanics : Targets and Therapy, 5, 33-44. doi:10.2147/BTAT.S66308

Sharma, A., Shanker, C., Tyagi, L. K., Singh, M., \& Rao, C. V. (2008). Herbal Medicine for Market Potential in India: An Overview. Academic Journal of Plant Sciences, 26-36.

Shi, M., Chiang, J., \& Duk Rhee, B. (2006). Price competition with reduced consumer switching costs. Management Science, 52(1), 27-38. doi:10.1287/mnsc.1050.0466

Sinha, A., \& Singh, N. (2015). Growing Herbal Cosmetics Indian Market. International Journal of Management and Science. Assessed at http://4dinternationaljournal.com/growing-herbal-cosmetics-indian-market/

Sriram, S., Subramanian, B., \& Manohar, U. K. (2007). Monitoring the Dynamics of Brand Equity Using StoreLevel Data. Journal of Marketing, 71(2), 61-78. doi:10.1509/jmkg.71.2.061

Stjernberg, L., Berglund, J., \& Halling, A. (2006). Age and gender effect on the use of herbal medicine products and food supplements among the elderly. Scandinavian Journal of Primary Health Care, 24(1), 50-55. doi:10.1080/02813130500475522 PMID:16464815

Subrahmanian, M., \& Venkatesan, R. P. (2011). Awarness on Ayurvedic System of Medicine in Chennai City. International Journal of Multidisciplinary Research, 1(2), 37-45.

Taleghani, M., \& Taghizadeh, M. (2012). Assessment of Gender Differences in Brand Loyalty of Sportswear Consumers (Case Study: A Sport Shops in the City of Rasht). Journal of Basic and Applied Scientific Research, 2(3), 2138-2144.

Tavşancıl, E. (2010). Tutumların ölçülmesi ve SPSS ile veri analizi [Measurement of attitudes and data analysis with SPSS] (4th ed.). Nobel.

Thaisorn, R., Byaporn, N., \& Chanchai, B. (2012). Thai Consumers "e Perception on Herbal Cosmetic Products: A Comparative Study of Thai and Imported Products. Information Management and Business Review, 4(1), 35-40. doi:10.22610/imbr.v4i1.961

Vaish, T. (2006). Promotion and Communication Strategies for Rural Markets in India. Marketing Mastermind, $8(3), 10-12$.

Vigneron, F., \& Johnson, L. W. (2004). Measuring perceptions of luxury. Journal of Brand Management, 11(6), 484-506. doi:10.1057/palgrave.bm.2540194

Wilson, A., Zeithaml, V., Bitner, M., \& Gremier, D. (2008). Services marketing: integrating customer focus across the firm (First European Edition). McGraw Hill.

Zeithaml, Z. A. (1988). Consumer Perceptions of Price, Quality, and Value: A Means-End Model and Synthesis of Evidence. Journal of Marketing, 52(3), 2-22. doi:10.1177/002224298805200302 
Richa Misra $(P h D)$ is working as an Associate Professor in Jaipuria Institute of Management, Noida. She has done her Doctorate in Management from Amity University. She has more than 17 years of teaching experience in the field of IT and Decision Science. Her research papers and cases has been published in reputed refereed journals like International Journal of Management Eductaion, Elsevier, On the horizon Emerald, International Journal of Logistics and Economics (Inderscience), Journal of Information and Organizational Sciences, ECCH, Abhigyaan (FORE), BHU (IT), IBS Business Review, Smart Journal of Management, Fortune Business Review and International Islamic University Malaysia. She has also presented her Cases and Research in various international conferences and forums. She has imparted trainings in various organizations in the areas of IT Security, Qualitative and Quantitative research methods, Data analysis and decision making and Quantitative techniques for HR and Marketing perceptive. Richa can be reached at richa.misra@jaipuria.ac.in.

Sonali Singh $(P h D)$ is working as an Assistant Professor in Jaipuria Institute of Management, Noida. She has done her M.Phil in Operations Research from University of Delhi and pursuing Ph.D from Amity University in Total Quality Management. She has more than fourteen years of teaching experience in the field of Business Statistics, Operations Research, Research Methods and Business Analytics. She has published various research papers in national and international journals of repute. She has been regularly participating in national and international conferences. She has been actively conducting MDP's in the areas of Inventory Management, Multivariate Data Analysis, and related fields. Sonali can be reached at sonali.singh@jaipuria.ac.in.

Renuka Mahajan (PhD) is an academician, trainer, and researcher, with more than 20 years of experience in the field of Information Technology and Software Engineering. At present, she is working as an Assistant Professor (IT \& Operations) at Jaipuria Institute of Management, Noida. Her research papers and articles have been published in reputed refereed journals Springer, Inderscience IJIL, IJLEG, IJPD, IJDATS, Journal of Information and Organizational Sciences, Journal of Engineering and Manufacturing, International Journal of e-Education, e-Business, e-Management and e-Learning to name a few. She has imparted training and conducted ICT workshops in the areas of Data warehousing and mining. Renuka can be reached at renuka.mahajan@jaipuria.ac.in. 